\title{
The influence of student motivation on student achievement in junior high school
}

\author{
Dessy Arie Gusman ${ }^{1}$, Happy Fitria ${ }^{2}$, Rohana Rohana ${ }^{3}$ \\ ${ }^{1}$ Sekolah Menengah Pertama Negeri 40 OKU, Indonesia \\ ${ }^{2}$ Universitas PGRI Palembang, Indonesia
}

\section{Article Info}

\section{Article history:}

Received Jul 13 $3^{\text {th }}, 2021$

Revised Aug $17^{\text {th }}, 2021$

Accepted Aug $30^{\text {th }}, 2021$

\section{Keyword:}

Student learning motivation

Student learning achievement

\begin{abstract}
This study aims to determine and analyze the effect of student motivation on student achievement in Junior High School 40 OKU. This type of research is quantitative. The sample in this study was 96 students of Junior High School 40 OKU. Data were collected using a questionnaire, documentation, and observation. Data were analyzed using the SPSS program. The results of this study suggest that there is an effect of student motivation on student achievement. This paper is expected to be useful for school policymakers in increasing student motivation and student achievement.
\end{abstract}

(C) 2021 The Authors. Published by IICET

This is an open access article under the CC BY-NC-SA license

(https://creativecommons.org/licenses/by-nc-sa/4.0

\section{Corresponding Author:}

Gusman, D. A.,

Sekolah Menengah Pertama Negeri 40 OKU, Indonesia

Email: dessyarieg@gmail.com

\section{Introduction}

We cannot avoid the progress of the times. We can only follow every change that exists. Therefore, in the face of a change, Human Resources (HR) are needed who are expected to be able to master every change that exists, especially in the development of science and technology which is increasingly advanced. To improve the quality of human resources, education is seen as having an important role in shaping the quality of the nation's next generation. [1] National education has the function of developing abilities, shaping dignified national character and civilization to educate the nation's life, aiming at developing the potential of students to become human beings who believe and fear God Almighty, have a noble character, are healthy, knowledgeable, capable, creative, independent and become a democratic and responsible citizen.Educational attainment in schools shows various kinds of results obtained by students during the learning process.

The achievement of this learning achievement can be seen based on the assessment of learning outcomes conducted by the teacher. [2] learning outcomes or learning achievements include three abilities possessed by students including cognitive, affective, and psychomotor domains. These three abilities are expected to be achieved properly and even very well so that the learning achievement of students can be seen whether it is by the desired learning objectives.

Learning achievement is realized because there are factors that influence it. [3] internal factors in the form of student learning motivation can affect learning achievement. 
Based on the above statement, some factors influence learning achievement, namely the encouragement from within the individual himself to achieve achievement. This impulse is what we call motivation. Motivation has a very important role in improving learning outcomes and motivation is also one of the supports in realizing this success. This is in line with [7] theory of motivation, which explains that motivation is a process of pushing and maintaining goals by directing behavior.

Based on the results of the preliminary study conducted by the researchers at SMP Negeri 40 OKU on March 9 to 12, 2020. Based on the results of the documentation in the form of a list of student learning outcomes that are included in the Odd Semester report cards for the 2019/2020 Academic Year and researchers make observations based on the learning outcomes. Researchers obtained data on student learning achievement classified as low in the subject of Social Sciences (IPS). Therefore, the learning achievement referred to in this study is the final value of the Social Sciences (IPS) subject in the form of numbers accompanied by letters as the predicate obtained from the report card scores.

This low learning achievement applies to all grades VII and VIII. This is evidenced from the list of report card scores where there are students who get a range of values between 63-74 including the predicate Enough (C) in the assessment of the cognitive and psychomotor domains. Meanwhile, in the affective domain, student learning achievement is in good and very good categories.

In this study, researchers will look further at learning achievement in the cognitive domain in social studies in the odd semester of the 2019/2020 school year at SMP Negeri 40 OKU.In connection with the internal factors that affect student achievement, namely the motivation or motivation to learn from students is still low. Based on the results of observations, it was seen that students were less active in participating in the learning process, there were still students who were sleepy during the learning process, there were still students who were lazy to do assignments or homework given by the teacher, there were students who disturbed their friends during the learning process. So, student learning motivation becomes one of the internal factors that cause students not to achieve maximum learning achievement, especially in social studies subjects.

The success in a learning process can be marked by the learning achievements obtained by students. [4] Explains that learning achievement is the achievement obtained by students in the form of impressions that cause changes in individuals after participating in the learning process. Furthermore, [5] explains that: Learning achievement is the success achieved by students after taking the learning process such as having various knowledge and technology, having skills, and having attitudes and behaviors that are conducive to the progress of themselves, society, and the nation.

Based on the above understanding, the researcher concludes that learning achievement is the level of success achieved by students after carrying out the learning process in the form of cognitive, affective, and psychomotor as a whole. [6] Explains that learning outcomes or learning achievements include three abilities possessed by students including cognitive, affective, and psychomotor domains.

Success in learning is certainly supported by the factors that can support the realization of that success. Likewise, in achieving student achievement, some factors influence it. [5] explained that:

The factors that affect learning achievement include:1)Motivation or encouragement.2)Interest in learning for achievement.3)Aspirations for achievement.4)Determine learning objectives.5)Ethics for achievement.6)Personality patterns.7)Ambition and aspirations.8. Learning environment.Furthermore, one of the main factors affecting learning achievement [7] is a factor from within, including student motivation.

Based on the above opinion, the researcher concludes that learning achievement can be influenced by the first two factors: internal factors, namely from the students themselves, and external factors from the environment around students which are closely related to education.Some indicators can indicate the level of student achievement. This needs to be done by the teacher aiming to find out how much success is achieved in learning. To take these measurements by evaluating them by the teacher. Guba and Lincoln quoted [8] explained that:Evaluation is the implementation of quality control, assurance, and application of a system, based on certain considerations and criteria as a form of accountability for the implementation of activities carried out to make a decision.Furthermore, [2] explains that learning outcomes or learning achievements include three abilities, namely cognitive, affective, and psychomotor.

The low and high learning outcomes obtained by students cannot be separated from the influence of motivation of students, students who have motivation in learning are certain to have better learning achievement than students who have less motivation in learning. Motivation to learn is an inner drive influenced by internal and external factors in students who are learning to make behavioral changes [2] Furthermore, [5] said that learning motivation is a unit that cannot be separated from the whole learning. 
To see the student's motivation to learn, various indicators can be used to measure whether the student is motivated to learn. The indicators of learning motivation according to [9] indicators of learning motivation are: 1) Choice of assignments, 2) Effort, 3) Persistence, and 4) Achievement. Furthermore, [10] states that the indicators of learning motivation can be classified as follows:1)The desire and desire to succeed.2)There are an encouragement and a need for learning.3)The existence of hopes and dreams for the future.4) There is an appreciation for learning.5)The existence of activities that are interesting in learning.6)The existence of a conducive learning environment that allows students to learn well.

Based on the expert opinion above, the researchers conclude that the indicators of learning motivation include: 1) Increasing student attention to learning, 2) Increasing student needs in learning, 3) Increasing student self-confidence during the learning process, 4) Increasing students' sense of appreciation towards learning, 5) Improve student achievement.

In this study, researchers used indicators of learning motivation according to Schunk as follows: 1) task choice, 2) effort, 3) persistence, and 4) achievement. The reason the researcher uses the theory of learning motivation indicators according to Schunk is that this theory is relevant to the problem to be investigated by the researcher, namely that there is an influence between student learning motivation on student achievement.

The results of research by [11] suggest that based on data processing and analysis through the SPSS 16.0 program, a correlation coefficient ( $\mathrm{r}$ ) of 0.693 means that learning motivation and student achievement have a significant effect, it can be concluded that there is a motivation influence. learning on science learning achievement with high-reliability level interpretation data, the magnitude of the influence of learning motivation on science learning achievement is $48.1 \%$. Based on the results of previous research, it appears that learning motivation influences learning achievement. The results of this study are in line with the opinion of [5] explaining that learning achievement can be achieved because of the factors that influence it, including motivation or encouragement.

\section{Method}

This research is research using a quantitative approach to find the effect of student motivation on student achievement at SMP Negeri 40 OKU. In this study, there is one independent variable and one dependent variable. Student learning motivation as the independent variable (independent) is stated as X, while student achievement as the dependent variable is stated as Y.

In conducting research, data collection techniques are needed to obtain the necessary data. According to [12], data collection techniques can be carried out by researchers through interviews, questionnaires, observations, and documentary studies. The data collection techniques in this study used a questionnaire technique (questionnaire), documentation, and observation.

According to [13], most research generally collects data using a questionnaire or questionnaire technique as the method chosen. Furthermore, [14] explains that the questionnaire is a data collection technique by giving a set of questions or written statements to respondents to answer. The questionnaire in this study used a closed questionnaire in which the answer to the questionnaire or statement was available so that the respondent only had to choose the answer that was already available by the real conditions and was aimed at students to find out student learning motivation.

The student learning motivation variable in this study will be measured using a Likert scale. Likert scale with five alternative answers, namely strongly agree, agree, doubt, disagree, and strongly disagree with scores of $5,4,3,2$, and 1 [15].In connection with the documentation technique, the documentation technique in this study is used to find out the data needed and considered important in the research conducted by the researcher. The results of the documentation in the form of odd semester report cards for the 2019/2020 school year are used to see student achievement at SMP Negeri 40 OKU.

The observation technique in this study is only used as a complement to strengthen and find out existing data information. The observation technique was used during the preliminary study to obtain data on student learning motivation and student achievement at SMPN $40 \mathrm{OKU}$. This observation technique is used by the researcher along with the documentation technique in the form of odd semester report cards for all grades VII and VIII during the preliminary study. The results of the documentation in the form of the values in the report card were made observations to see student achievement in social studies subjects in the odd semester of the 2019/2020 school year.

The subjects in this study were students of SMP Negeri 40 OKU. Sampling is done by sampling technique with a probability sampling technique using simple random sampling (simple random sampling). [12], simple 
random sampling of all individuals who are members of the population have the same opportunity and are free to be selected as members of the sample, because these individuals have the same characteristics.

In this study, the sampling was obtained from the study population consisting of five classes with a total of 127 students, the sample was taken from the population by simple random. The sample size was calculated using the Slovin formula. The sample obtained was 96 students of SMP Negeri 40 OKU. The sample consisted of class VII students. A VII. B, VII. C, VIII. A, and VIII.B.

The research data were obtained by using a questionnaire to determine the effect of student motivation on student achievement. Furthermore, student learning achievement data obtained from the results of documentation in the form of odd semester report cards for the 2019/2020 academic year are used to see student achievement, especially in social studies subjects. The instrument used has gone through validation and reliability stages. Validation is obtained from experts and the results of field trials. The data analysis process in this study includes tabulating the data for each variable, then calculating the data assumption test, and then testing the hypothesis. Data processing is assisted by the SPSS Version 21 program.

\section{Results and Discussions}

Based on the results of data processing collected from 96 students of SMP Negeri 40 OKU, the descriptive statistics table shows that the mean (average) value is 79,73, the highest value is 100 and the lowest value is 54 .

Meanwhile, the results of testing with the regression model show that the results of testing the hypothesis using the t-test are significantly accepted. Based on the results of data analysis, the sig value is obtained. equal to $0.000<0.005$, so it can be concluded that the student learning motivation variable (X1) affects the student achievement variable (Y). Furthermore, it is known that the $t$ value is 9,290. Furthermore, we compare the calculated $t$ value $(9,290)>t$ table $(1,989)$. Based on the comparison between the $t$ value and the $t$ table value, it is stated that the $t$ value is greater than the $t$ table, so Ho is rejected and $\mathrm{Ha}$ is accepted. Then, the magnitude of the influence of the independent variable (student learning motivation) on the dependent variable (student achievement) is $47,9 \%$. These results indicate that student motivation has a significant effect on student achievement.

The value obtained in this study proves that student learning motivation affects student achievement. Student motivation is one of the factors that can affect student achievement. This is in line with the opinion of [7] that learning achievement is influenced by internal factors including student motivation.

Student learning motivation should be increased so that student achievement will also increase. [9] indicators of learning motivation consist of 1) task choice, 2) effort, 3) persistence, and 4) achievement. The four indicators should be achieved by students optimally so that they also affect student achievement.

\section{Conclusions}

Based on data analysis and hypothesis testing, it can be concluded that there is a significant effect of student learning motivation on student achievement at SMP Negeri 40 OKU.

\section{References}

Law Number 20 of 2003. National Education System. Jakarta: SL Media.

Suprijono, Agus. 2015. Cooperative Learning. Yogyakarta: Learning Library.

Slameto. 2013. Learning and the factors that influence it. Jakarta: PT. Rineka Cipta.

Hamdani. 2011. Teaching and Learning Strategies. Bandung: Faithful Library.

Rusyan, Tabrani. 2013. Building Quality Teachers. Jakarta: CV. Dhanama Creative Mandiri.

Suprijono, Agus. 2010. Cooperative Learning Theory and Applications of PAIKEM. Yogyakarta: Student library

Shah, Muhibbin. 2006. Learning Psychology. Jakarta: PT. Raja Grapindo Persada.

Arifin, Zainal. 2013. Concepts and Models of Curriculum Development. Bandung: PT. Rosdakarya youth.

Schunk, 2012. Learning Theories of Educational Perspectives. Eva H and Rahmat F, translators. Yogyakarta: Student Library. Translation from: Pearson Education.

Uno, H. B., 2013. Theory of Motivation \& Its Measurement. Jakarta: Earth Literacy. 
Hamdu, Ghullam and Lisa Agustina. 2011. The Effect of Student Motivation on Science Learning Achievement in Elementary Schools. Journal of Educational Research. 12 (1): 85.

Sukmadinata. 2010. Educational Research Methods. Bandung: PT. Rosdakarya youth.

Arikunto, Suharsimin. 2010. Research Procedure A Practice Approach. Revised Edition. Jakarta: Rineka Cipta.

Sugiyono. 2013. Qualitative and Quantitative Research Methods R \& D. Bandung: Alfabeta

Priyono. 2016. Quantitative Research Methods. Surabaya: Zifatama Publishing. 